Krystyna Pietrych

Uniwersytet Łódzki

\title{
Młodzieńcze intermedia Aleksandra Wata (Anatola Sterna i Henryka Berlewiego)
}

Awangarda pierwszych dekad xx wieku była zjawiskiem złożonym, nie tylko jeśli chodzi o wielość i różnorodność współtworzących ją kierunków i nurtów artystycznych, ale także ze względu na wielorakie relacje i zależności pomiędzy dziedzinami sztuki. W odniesieniu do związków łączących literaturę i malarstwo, jak słusznie zauważyła Beata Śniecikowska:

przekraczanie granic znakowych, wizualizacja tekstu, różnorakie literacko-plastyczne uwikłania to jedne z zasadniczych problemów sztuki modernistycznej, zwłaszcza w jej awangardowym wcieleniu. Innowacyjność literatury i plastyki jest tu jednocześnie odpowiedzią na wielorakie wyzwania nowoczesnej cywilizacji oraz - $\mathrm{z}$ drugiej strony - na związane z nimi nowe możliwości kreacji artystycznej (Śniecikowska 2006: 6).

Diagnoza ta odnosi się zarówno do europejskich, jak i do rodzimych poszukiwań i realizacji estetycznych. Silne związki sztuki słowa i obrazu to przecież nie awangardowy wynalazek, jednak - zauważa Maria Delaperrière:

Nigdy dotąd wpływ malarstwa na literaturę (przede wszystkim poezję) nie objawiał się z taką siłą, jak właśnie w awangardach. Zjawisko tym bardziej znaczące, że dotąd w tradycji estetycznej raczej literatura inspirowała malarzy, dostarczając im motywów, tematów, symboli (cyt. za: Śniecikowska 2006: 176). 
Ta zmiana kierunku oddziaływania wydaje się szczególnie znacząca - literatura w swej tradycyjnej postaci traci pozycję dominującą, stając się w dużej mierze tworzywem plastycznym. Nieco inaczej rzecz widział Zbigniew Bieńkowski, odnosząc się do działalności Awangardy Krakowskiej:

W czasach „Zwrotnicy”, „Linii” związki nowej poezji z nowym malarstwem były ścisłe i trwałe. Śmiałość poezji i śmiałość malarstwa nie tylko się uzupełniały, ale i dopingowały wzajemnie w poszukiwaniu coraz nowszej nowości. To nie była tylko współpraca, to było współuczestnictwo w atakowaniu nowych terenów wyobraźni (cyt. za: Śniecikowska 2006: 176).

Bez względu jednak na to, czy którejś ze sztuk przyznamy pierwszeństwo, czy też opowiemy się za równorzędnością oddziaływania, faktem niezaprzeczalnym pozostaje ich nierozerwalna współobecność w ramach awangardowych poszukiwań i eksploracji nowych obszarów artystycznej kreacji. Ta oglądana z dzisiejszej perspektywy specyfika awangardowej działalności, łączącej różne dyskursy i tradycyjnie odrębne dziedziny sztuki, ujawnia zaskakująco dużo podobieństw z przedmiotem współczesnej refleksji dotyczącej funkcjonowania poezji jako medium łączącego elementy językowe, wizualne i dźwiękowe, które można i należy badać nie tylko literaturoznawczymi narzędziami - dziś trudno się zgodzić ze stanowiskami przypisującymi obrazowości w poezji charakter czysto lingwistyczny. Warto poszukiwać kategorii zaczerpniętych z innych dyskursów, przydatnych do analizy i opisu doświadczeń awangardy. Tę potrzebę ostatnimi czasy uświadomił dobitnie zwrot ikoniczny, którego jednym z najważniejszych postulatów było odejście od czytania obrazów jako odpowiednika lektury tekstu. Jak trafnie zauważyła Anna Kałuża:

Konsekwencją zwrotu obrazowego i podjęcia badań nad artystycznością w transmedialnej perspektywie byłyby, najogólniej mówiąc, dwa efekty: unieważnienie prymatu językowego modelu dla wszystkich innych reprezentacji, ekspresji i praktyk artystycznych oraz próba pomyślenia niebinarnego układu kulturowego, w ramach którego uznaje się, że wszystkie media są mediami mieszanymi (Kałuża 2020: 51).

W dobie kultury wizualnej, którą awangardowe eksperymenty niewątpliwie antycypowały, warto byłoby spojrzeć na nasze rodzime „-izmy” początku poprzedniego stulecia inaczej niż dotychczas, tzn. odchodząc od postaw stricte literaturocentrycznych, stojących na straży odrębności poszczególnych sztuk, 
na rzecz oglądu bardziej całościowego, w którym żadna dziedzina nie jest ani uprzywilejowana, ani całkowicie osobna, a żaden dyskurs nadrzędny lub podrzędny wobec innego. Chciałabym przyjrzeć się w tej perspektywie niektórym tzw. futurystycznym wystąpieniom Aleksandra Wata współtworzonym wraz $\mathrm{z}$ innymi uczestnikami działań awangardowych. Tak więc nie będzie mnie tu interesować spojrzenie historycznoliterackie, nie będę również podejmować kwestii ikoniczności literatury czy zajmować się problematyką ekfrazy. Jeśli elementy tego typu rozważań się pojawią - to marginalnie i przygodnie. Chcę usytuować dokonania autora namopaników (i jego współtowarzyszy), ze względu na ich kształt werbalno-obrazowy, w przestrzeni transmedialnej. Warto raz jeszcze przytoczyć słowa śląskiej badaczki:

Na realizacje ujmowane dotąd w ramach dwóch różnych systemów, uznawanych za konkurencyjne lub przekładalne na siebie, można spojrzeć z perspektywy transmedialnej. [...] Najważniejsze w tym kontekście wydaje się przekonanie, że wszystkie poetyckie realizacje są obrazowo-wizualne, nie tylko te, które mają komponent niewerbalny czy niepiśmienny (Kałuża 2020: 40).

Powyższe sądy stanowią dla mnie bezpośrednią inspirację do podjęcia analizy dokonań młodego Wata w horyzoncie zakreślonym poprzez zwrot pikturalny, w którym ujawnić by się mogła heterogeniczność medium rozpatrywanego dotąd przede wszystkim jako tekst literacki. Nadal najważniejsza pozostaje dla mnie perspektywa, w której miejsce osobne zajmuje literatura, nieoglądana już jednak przede wszystkim pod kątem literaturocentrycznym, lecz ujmowana w optyce integrującej wielość różnorodnych dziedzin sztuki ${ }^{1}$.

Tomasz Załuski pisze:

W odróżnieniu od intermedialności, akcentującej element syntezy praktyk związanych z różnymi mediami, transmedialność odsyła do dynamiki przejścia danej praktyki z jednej dziedziny medialnej w inną, a także akcentuje wewnętrzną heterogeniczność powstającego w tym procesie wytworu (Załuski 2010: 11).

1 „Narratologia klasyczna była tekstocentryczna, ahistoryczna i uniwersalistyczna, skoncentrowana na badaniu zamkniętych systemów konstruowanych metodami oddolnymi (bottom-up) i opartych na opozycjach binarnych; narratologia postklasyczna jest zorientowana na kontekst, historyczna, skoncentrowana na jednostkowości dzieła i otwartych, dynamicznych procesach znaczeniotwórczych analizowanych jako całość (podejście odgórne, top-down) wraz z ich kontekstem kulturowym" (Kaczmarczyk 2017: 34-35). 
Oczywiście, oba terminy stosowane są przede wszystkim w odniesieniu do współczesnej kultury medialnej. Sądzę jednak, że ich użycie w kontekście awangardowych dokonań może przynieść ciekawe efekty, tym bardziej, że - podążając tropem łódzkiego kulturoznawcy - warto zadać wynikające z przyjęcia takiej perspektywy pytania i wykorzystać je do określenia specyfiki eksperymentów początku Xx stulecia:

Co się [...] dzieje, zanim „krzyżujące” się sztuki ulegną syntezie i dadzą początek nowemu (inter)medium? Co się dzieje, gdy do takiej syntezy w ogóle nie dochodzi, gdy ze „skrzyżowania” sztuk powstaje heterogeniczna hybryda, utrzymująca się w orbicie oddziaływania nazwy danej praktyki artystycznej, rozszerzająca, redefiniująca lub rozrywająca jej ramy, bądź też zdająca wymykać się jednoznacznemu nazwaniu? Jak odnieść się do sytuacji, w której wartością staje się nie synteza i unifikacja, lecz sama „tranzytowość”, „przechodniość”? (Załuski 2010: 11).

Pytania te, dotyczące statusu owego „nowego (inter)medium”, wyznaczają pole, w którym chciałabym usytuować programowe wystąpienia młodego Wata, tak by wydobyć ich wizualną swoistość niedającą się zredukować (co zazwyczaj czyniono) do dyskursu językowego i medium pisma.

Jednodniówka TAK wiodła do niedawna żywot na pół legendarny. Wat we Wspomnieniach o futuryzmie z początku 1930 roku, a więc ponad dekadę od jej publikacji, pisał:

Pierwszym występem była mała ulotka na błękitnym papierze zatytułowana Tak. Przypominam sobie tylko jedno zdanie: „owrzodziałe słupiska tomaszowej niewiary". Z tego frazesu i tytułu można sobie o niej urobić pojęcie: była naszpikowana symbolami i głosiła bezwzględną aprobatę dzisiejszości (Wat 2008: 138)².

Ulotka odnaleziona została ostatnio w zbiorach Egido Marziona, o czym pisze dokładnie Śniecikowska, dzięki której z tą publikacją mógł po raz pierwszy zapoznać się szerszy odbiorca (zob. Śniecikowska 2019: 336-337). Porównanie tego, co Wat zapamiętał, z tym, co widnieje na niewielkiej kartce, nie tylko

2 Por. ciekawą analizę zapamiętanego przez Wata fragmentu w: Graf 2018: 19-21. 
ujawnia mistyfikujące działanie pamięci, przekształcające „tomaszowe słupiska zgrzybiałego chramu / owrzodzone kolumny” w „owrzodziałe słupiska tomaszowej niewiary” ale również - co istotne - pozwala określić kolorystykę tła oraz wskazać jednoznacznie autorską intencję; oczywiście, jeśli w tym względzie zawierzyć pamięci Wata. Wydaje się jednak, że łatwiej zapamiętać dominującą barwę i zamierzony cel publikacji niż konkretne zdanie w jego pierwotnym, oryginalnym kształcie.

Tak opisuje pierwszą publikację polskiego futuryzmu³ jej pierwsza badaczka:

Cieniutka kartka zeszytowego formatu, w niczym nieprzypominająca wielkoformatowych płacht późniejszych manifestów polskiego futuryzmu, niegdyś najpewniej błękitna, dziś pożółkła, lekko zielonkawa. Bibułkowy papier doskonale przechował jednak awangardowe - choć kojarzone głównie z konstruktywizmem - kontrasty czerwieni i czerni liter oraz, naturalnie, same kontrasty rozmiaru czcionek. Rozchwiany słup druku musiał u progu międzywojnia dezorientować dość przypadkowych odbiorców: rzecz napisana przez nastoletnich jeszcze Aleksandra Wata i Anatola Sterna, ukazała się najpewniej pod koniec 1918 lub na samym początku roku 1919 (Śniecikowska 2019: 331-333).

Zacznijmy od kształtu materialnego raz jeszcze - to, co widzimy, wydaje się bowiem na początku istotniejsze, od tego, co możemy (nie bez trudu) przeczytać. Zwłaszcza w pierwszym momencie, gdy rzucamy na ulotkę okiem, postrzegamy zrazu kilka jej cech wizualnych. Po pierwsze, gdy była jeszcze błękitna, barwę nieoczywistego i niecodziennego tła. Po drugie, rozkołysaną, rozedrganą, jakby niestabilną kolumnę tekstu, zapisanego w dziwnie niesystemowy, „niespokojny”, a więc rozbijający statyczność pisma sposób, eksponujący zaś jego dynamikę. Ten graficzny brak ładu i spójności realizowany jest zarówno w przestrzeniach międzywersowych (różne, „skokowe” odległości pomiędzy wersami), jak i w odstępach pomiędzy słowami w poszczególnych linijkach, co może w jakiejś mierze przypominać schodkowe wiersze Majakowskiego. Po trzecie, choć krój czcionki jest konsekwentnie ten sam, to kontrastuje ona rozmiarem, pogrubieniami, pojawiającymi się małymi i wielkimi literami i, oczywiście, zastosowanymi kolorami: czarnym i czerwonym. Na pierwszy rzut

3 Mianem futurystycznej zwykło się określać młodzieńczą twórczość Wata. Można mieć wątpliwość, co do trafności tej nazwy, bowiem większe powinowactwa łączą, moim zadaniem, awangardowe dokonania autora Mopsożelaznego piecyka $\mathrm{z}$ dadaizmem. Pisałam o tym w tekście Dadaistyczne $z$ ducha poszukiwania młodego Wata (zob. Pietrych 2017). 


\section{T A K}

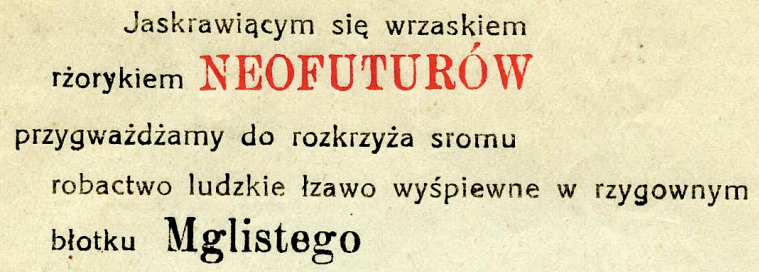

Kruszymy zębami brzeżki kruża lawiąc wargi swe i sklepienie swego nieba alkoholem eteru Krzyczymy ciałem swoim

\section{SIEBIE}

w glorzystym Pramuskule

słoncowe ziemie $z$ mordami spienionemi

\section{od śmigu nam nieznane}

wkolysane w rytmy fal fal rytmu nie znaja

zmorne szaleństwo rozżarzonych kraterów miast

\section{Jesteśmy}

tomaszowe slupiska zgrzybialego chramu

owrzodzone kolumny

rozkonwulsjowane upojnie w podrygach

$$
\text { Czekamy na Niego }
$$

PRZYJDŹ

\section{NEOFUTURZY}

Ryc. 1. Ulotka тAк. Za udostępnienie dziękuję Beacie Śniecikowskiej. 
oka typografia może sprawiać wrażenie zbyt pośpiesznie złożonej, byle jakiej, niepokojąco niezbornej. Właśnie owa „niezgrabność” wizualna działa na odbiorcę w pierwszym kontakcie najsilniej, prowokując do podjęcia prób okiełzania chaotycznego obrazu i poszukiwania jakiejś reguły organizującej całość. Jest kilka elementów, które mogą stać się stabilizującymi punktami oparcia. Taką funkcję pełni quasi-symetryczna konstrukcja tekstu opierająca się na zapisanych wersalikami: inicjalnym TAK i końcowym PRZYJDź oraz środkowym, zapisanym kolorem czerwonym dystychu: siebie / w glorzystym Parmuskule. Przy czym elementami wprowadzającymi wizualny porządek są tu nie tylko wielkie litery, ale również podział wyraźnie segmentujący tekst na dwie symetryczne części z krótkim, dwuwersowym fragmentem pośrodku, pełniącym rolę wizualnego centrum komunikatu. Elementy porządkujące osłabione zostają jednak poprzez kapryśne pojawianie się w drukowanej rozfalowanej kolumnie słów zapisanych kolorem czerwonym w przypadkowych miejscach, sprawiających wrażenie, jakby wybrano je na chybił trafił.

Czy te pierwsze wrażenia wzrokowe mają jakieś znaczenie? Sądzę, że niebagatelne, ponieważ to one inicjują proces lektury tekstu, a następnie go w istotny sposób kształtują. W efekcie nie daje się oddzielić wymiaru graficznego i dyskursywnego ulotki. Śniecikowska uważa, że

Pośród kompozycji sprzed stu lat „na oko” najbliżej ulotce do publikowanych w prasie tekstów reklamowych operujących czcionkami różnych wielkości i krojów, zawieszonych między graficznym porządkiem prozy i poezji. Podobieństwo do druków reklamowych jest jednak dość powierzchowne, w znacznej mierze - czysto wizualne (Śniecikowska 2019: 333).

Podobieństwo jest w istocie wizualne, ale to nie znaczy, że powierzchowne. Strategia budowana typografią ma znaczący wpływ na aktywizowanie całościowych sensów ulotki Wata i Sterna. Z pewnością ma działać - w pierwszym kontakcie - właśnie jak doraźny druczek reklamowy niewielkich rozmiarów, łatwo podatny na zniszczenie (bibułka), sugerujący poniekąd własną nieważność i efemeryczność. To jak gdyby antycypacja i realizacja jednocześnie w materialnym wymiarze postulatu o chwilowości poezji z późniejszego manifestu Jasieńskiego ${ }^{4}$. To również, po pierwsze, wyrażona rozchwianym i niezgrabnym drukiem polemika $z$ dotychczasowym jednostajnym, ustabilizowanym wer-

4 „Bezwzględna wartość dźeła sztuki waha śę pomiędzy 24 godźinami a miesiącem” (Jasieński 1978: 22, zachowano oryginalną pisownię). 
syfikacyjnie kształtem tekstu literackiego, zwłaszcza w jego stroficznym bądź stychicznym wydaniu i, po drugie, zerwanie z jednostajnością grafii na rzecz zmienności i dynamiki, co miało zapewne stanowić wizualny ekwiwalent współczesności z jej ciągle przyśpieszającym tempem miejskiego życia, z aktywizmem i energią, którą dodatkowo wyrażał czerwony kolor - kontrastujący z tłem, ekspresyjny, tak że litery zdawały się „wyskakiwać” ponad płaszczyznę druku. Powyższe znaczenia ikoniczne wspiera porządek leksykalno-składniowy tekstu. Z jednej strony - parodystycznie przywoływany krąg znaczeń młodopolskich, z drugiej - sensy oscylujące wokół nowego porządku, którego figurą staje się gloryfikowana fizyczność. Istotny wydaje się fakt, że semantyka tekstu jest tutaj wymiarem budowanym na grafii i poprzez nią, nie istnieje więc samodzielnie, lecz dzięki medium wizualnemu. Jak słusznie zauważyła Agnieszka Karpowicz:

Pozornie pismo alfabetyczne, szczególnie w porząaku typograficznym drukowanej stronicy, wydaje się niematerialnym, niemal przezroczystym naczyniem na treść bezpośrednio zapośredniczoną przez mowę. Słowo pisane jest jednak zawsze formą postrzeżeniową, przy czym jej specyfika polega na tym, że patrzymy równocześnie na nią i przez nią" (Karpowicz 2010: 123).

W przypadku ulotki TAK niewystarczająca wydaje się lektura stricte literaturocentryczna, pomija ona bowiem istotne sensy przekazu i nie pozwala ustabilizować treści skierowanych do odbiorcy komunikatu. Warto zatem zawierzyć najpierw temu, co widzi oko, a dopiero po chwili temu, co czyta. A w pierwszym momencie widzi rozchwiany, budujący dość chaotyczną kolumnę tekst, w którym uwagę zwraca kilka elementów wyróżniających się spośród pozostałych - bądź to zapisem wersalikami lub inicjalną wielką literą, bądź to czerwoną barwą. W efekcie najpierw czytamy właśnie te wyróżnione graficznie, jakby „wyskakujące” z tekstu słowa. Inicjalne TAK „krzyczy” sposobem zapisu, a dopiero w dalszej kolejności poprzez występowanie w kontekście sąsiadujących słów: „wrzaskiem” i „rżorykiem”. Nie mogę się zatem zgodzić z interpretacją pierwszej badaczki ulotki, piszącej:

Tak. Jaki łagodny początek. Zaskakujący w kontekście tytułów późniejszych futurystycznych manifestów i jednodniówek [...]. Tak. Afirmacja. Spokój. Zgoda.

Czy to jednak aby najlepszy szyld dla pierwszego wystąpienia artystycznych wichrzycieli? Takie zawołanie na rewolucyjny początek?! 
Gdyby upierać się przy chwytliwych, krótkich partykułach - o wiele lepsze wydaje się „nie” (Śniecikowska 2019: 337).

Jeśli czytać TAK zapisane wielkimi literami, niepodobna wyczytać tu łagodności, spokoju, a nawet zgody. To TAK krzyczy, coś afirmując, ale jeszcze nie wiemy co. Choć Śniecikowska bierze pod uwagę i taki wariant zasugerowany przez Pawła Grafa: „może to istotnie «Tak - rzucone nadejściu nowych antymetafizycznych czasów i wykrzyczane w tytule manifestu»?" (Śniecikowska 2019: 337; zob. Graf 2018: 21), jednak przedstawia go jako hipotezę, której nie poddaje ostatecznej weryfikacji nawet poprzez przywołanie kontekstu późniejszej korespondencji Wata i Sterna. A przecież owa aprobata zyskuje w ulotce jednoznaczny sens: to TAK wykrzyczane przez NEOFUTURów afirmujących SIE BIE w glorzystym Pramuskule. Jeśli więc uwzględnimy kształt druku, odnajdziemy po chwili poszukiwany sens - są to bowiem te fragmenty, które poprzez zabiegi typograficzne widzimy/czytamy jako pierwsze ze względu na wizualną odrębność. Właśnie graficzna odmienność sugeruje ich nadrzędność w stosunku do pozostałego tekstu, a więc wydobywa wyjątkowe znaczenie tego, co w ten sposób jest przekazywane. A przekaz można mniej więcej tak zrekonstruować, biorąc pod uwagę wymiar ikoniczny: neofuturzy mówią tak sobie samym, swej sile i fizyczności oraz oczekują nadejścia „Niego”, prosząc: PRzYjDź. Dopiero teraz otwiera się droga do szczegółowej lektury tekstu werbalnego. To zadanie wykonała w dużej mierze Śniecikowska, prowadząc nas przez „meandry mikrolektury” (Śniecikowska 2019: 340). Badaczka tak konkluduje swoje dociekania:

Drobiazgowa mikrolektura Tak pozwoliła na przywołanie najróżniejszych kontekstów badawczych, nie udało się jednak wytyczyć konkretnej, wyrazistej ścieżki interpretacji. Nie widzę także w przenicowanej analitycznie ulotce dających się spójnie rekonstruować śladów programu artystycznego świeżo powstałej dwuosobowej grupy twórczej. Brakuje tu również wyraźnych świadectw „nakierowania na kontakt z odbiorcą” - mimo wyboru tak egalitarnej [...] formy publikacji (Śniecikowska 2019: 352).

Zacznijmy od końca. Jeśli za „wyraźne świadectwo” kontaktu z odbiorcą uznać jedynie bezpośrednie do niego kierowane pytania czy zwroty - to w istocie ich nie ma. Jednak kontakt nawiązywany jest za pomocą innych strategii. Najważniejsze wydają się tu zabiegi typograficzne. Kształt wizualny TAK wyznacza bowiem specyficzny tryb lektury - odbiorca „czyta” (lepiej chyba powiedzieć, że widzi i czyta jednocześnie) nie linearnie, ale punktowo. Przedmiotem jego 
percepcji jest szczególny, budowany słowami obraz, którego plan pierwszy wyznaczają wyrazy zapisane wersalikami (bądź wielką literą) i kolorem czerwonym, dopiero później pojawiają się w polu widzenia „leksykalne obiekty” drukowane czcionką mniejszą (czasem również czerwoną). To proces zgodny $\mathrm{z}$ temporalnym trybem postrzegania - najpierw widzimy elementy duże, potem mniejsze. Nie mamy tu więc do czynienia z jednostajnym oglądem całości, lecz z procesem rozłożonym na fazy (krótkie niczym mgnienie oka), którego etapy nie następują po kolei, lecz punktowo, wywoływane jakościami wizualnymi. Widzenie w taki sposób jest jak oglądanie obrazu - najpierw postrzegamy elementy większe i barwniejsze, by w miarę coraz uważniejszego patrzenia odkrywać składniki drobniejsze, zrazu mniej rzucające się w oczy. Z pewnej odległości widzimy tylko plan pierwszy, a gubimy detale - aby je odzyskać, musimy spojrzeć inaczej, przekształcić własną percepcję. Tak właśnie przebiega percepcja ulotki TAK. Odbiorca jest atakowany wizualnym kształtem obiektu, co jest skutkiem świadomych autorskich zabiegów zmierzających do intensyfikacji odziaływania i co w efekcie prowadzi do emocjonalnej reakcji (choćby negatywnej!) ze strony drugiego uczestnika procesu komunikacji.

Co do kwestii drugiej - „wytyczenia wyrazistej ścieżki interpretacji” - sądzę, że wskazują jej kierunek słowa samego Wata, które warto jeszcze raz przytoczyć: „[ulotka - K.P.] głosiła bezwzględną aprobatę dzisiejszości” (Wat 2008: 138). Zgodnie z intencją autorską, która stanowi w tym przypadku niezbywalny kontekst, TAK czytać należałoby jako anarchizujący tekst wymierzony we wczorajsze ideały, apoteozujący współczesność, zapowiadający nadejście nowego jutra i gloryfikujący fizyczność, siłę i dynamikę jako figury wyczekiwanej przyszłości.

I kwestia trzecia. Neofuturzy kreślą najpierw, nonszalancko i blasfemicznie, program negatywny, odrzucający wszelkie metafizyczno-estetyczne wartości młodopolskie. Dalecy są przy tym od formułowania swych idei w sposób racjonalny i dyskursywny - zresztą krzyk, którym się posługują, ze swej istoty takich własności nie posiada. Ale przecież poza negacją także coś wybierają, choć nie wyrażają tego w jasno formułowanych postulatach. To, co proponują, istotnie nie spełnia kryteriów manifestu zgodnych ze słownikową definicją. Z dzisiejszej perspektywy widać jednak wyraźnie, że młodzi neofuturzy dokonali pozytywnego samookreślenia nie na poziomie explicite wyrażonych haseł i idei (tak jak uczynią później na dwa odmienne sposoby Jasieński i Peiper), ale na poziomie „meta” - poprzez działania transmedialne, prowadzące do powstania nowego, wewnętrznie heterogenicznego obiektu. W TAK łączą się ze sobą jakości wizualne i werbalne, dając początek nowemu (inter)medium, oddziałującemu swoistą „przechodniością” zastosowanych tworzyw i jednocześnie stanowiącemu ich syntezę. Tylko w swym złożonym, graficzno-języ- 
kowym kształcie ulotka neofuturów aktywizuje bowiem pełną funkcjonalność semantyczną - czynnik wizualny nie może tu zatem zostać sprowadzony do roli ornamentacyjnego dodatku. Przeciwnie, ikoniczny wymiar pierwszego polskiego manifestu futurystycznego, destabilizując sensy, nadaje im dynamiczną procesualność, sprawia, że mamy tu do czynienia z wypowiedzią o charakterze performatywnym - chcącą oddziaływać skutecznie na rzeczywistość pozawerbalną oraz kształtować i wyrażać nowe jutro. Niewielka, ongiś błękitna ulotka, wspólne „dzieło” nastoletnich Sterna i Wata, eksponująca własną "graficzną materialność" (Karpowicz 2010: 124), była niczym jeden z elementów ówczesnej, ale w jakiejś mierze i dzisiejszej przestrzeni wizualnej budowanej przez „szyldy, napisy reklamowe, plakaty, wystawy sklepowe oraz witryny kiosków prezentujące typograficzne słowa na okładkach magazynów, pudełkach papierosów lub opakowaniach gumy do żucia” (Karpowicz 2010: 125). Wkraczała w ten sposób, jak zauważa badaczka,

w wizualną przestrzeń codziennego życia, a także [...] w publiczną i prywatną przestrzeń audialną. Ten wielkomiejski hałas futuryści chcieli wprowadzić także w milczącą przestrzeń obrazu lub drukowanej stronicy [...]. Zgiełk na kartce papieru miał według futurystów uobecniać w doświadczeniu bezpośrednim hałaśliwą rzeczywistość współczesnego im miasta (Karpowicz 2010: 128).

Młodociani warszawscy neofuturzy taki właśnie program realizowali i choć w swym wystąpieniu nie byli aż tak radykalni jak ich zachodni koledzy, to jednak odrzucając wszystko, co wyłoniło się z „błotka Mglistego”, opiewali „szaleństwo rozżarzonych kraterów miast”, ekwiwalentyzując wizualnie - w sposób dziś z pewnością nierewolucyjny, ale naonczas nowatorski - te „wybuchowe jakości” kwestionującym statyczność pisma układem graficznym widniejącym na ulotce.

Warto w tej perspektywie usytuować także kolejne wspólne wystąpienie Wata i Sterna - almanach Gga, „wielki kolorowy zeszyt” (Jarosiński 1978: XL) wydany w grudniu 1920 roku. Zawierał on dwa cykle wierszy i manifest zatytułowany Prymitywiści do narodów świata i do Polski. Najczęściej zajmowano się dotychczas właśnie manifestem, zwracając uwagę na awangardowe hasła odrzucające niegdysiejsze idee i reguły tworzenia, apoteozujące zaś nowe wartości i nową estetykę. Wiersze z kolei, opatrzone tytułami Muza na czworakach w przypadku tekstów Sterna, Fruwające kiecki - w przypadku Wata, są jawnie ironiczne i obrazoburcze w stosunku do wzniosłej twórczości młodopolskich poprzedników. Słusznie twierdził Wat po latach w rozmowie z Miłoszem: 
Mniejsza o wiersze, bo wiersze [...] staraliśmy się dać najgorsze, jakie można sobie wyobrazić. I rzeczywiście, celowo najbardziej nieudolne, niezgrabne dziwaczne, bezsensowne, ale bez tego nonsensu, który później się pojawił. To znaczy, programowe nieudolne, szkaradnie nieudolne (Wat 1998: 42-43).

$\mathrm{W}$ ten sposób młodzi obrazoburcy realizowali w praktyce jedno $\mathrm{z}$ haseł swojego manifestu: „wymiatamy z mętnej karczmy nieskończoności nędzne historyczne twory zwane poetami [...]. zamiast estetyki antygracja” (Wat 2008: 8). Zgadzam się zasadniczo z wyrażoną po latach opinią Wata co do wartości artystycznej zawartych w almanachu utworów poetyckich, choć ich wnikliwa analiza mogłaby przynieść bardziej zniuansowane wnioski. Nie to mnie jednak interesuje. Przyjrzeć się chcę nie tyle poszczególnym częściom publikacji, co już niejednokrotnie czyniono, ale całości zamkniętej pomiędzy stroną tytułową a ostatnim zdaniem i spytać o sensy ewokowane przez tę całość i zastosowane w niej rozwiązania typograficzne.

Piotr Rypson, znawca historii polskiego projektowania graficznego, pisze:

Szata graficzna miała epatować czytelnika, w oczywisty sposób kłócąc się z uznanym gustem. Już sam format dużego kwadratu $[30,5 \times 30,5 \mathrm{~cm}]$ był czymś dotychczas nieznanym; na oranżowym tle oczy kłuły duże, blokowe litery tytułu - GGA. Usunięcie wersalików i prowokujące tytuły wierszy dopełniały efektu (Rypson 2017: 33).

W stosunku do rozwiązań zastosowanych w ulotce TAK twórcy posunęli się zatem znacznie dalej. Duży, jaskrawego koloru kwadrat broszury musiał o wiele bardziej rzucać się w oczy zarówno rozmiarem, jak i barwą niż niewielka, błękitna ulotka. A wielkie, ciężkie, czarne, przypominające klocki litery prowokowały nie tylko zastosowaną czcionką, ale także wyraziście podkreśloną niedorzecznością i absurdem. Lektura kolejnych wierszy wzmacniała zaś poczucie nonsensu - semantyka tekstów jawnie kłóciła się nie tylko z dotychczasowymi przyzwyczajeniami czytelniczymi, ale także ze zdrowym rozsądkiem. Nadto znaczące jest posługiwanie się niecodzienną typografią: wytłuszczanie przypadkowych słów i zwrotów w wierszu nie w celu wyróżnienia (tak jak bywało dotąd) fragmentów o szczególnej wadze i znaczeniu, ale przeciwnie - pokazania, że gest graficzny może zwracać uwagę na to, co jest całkowicie pozbawione głębszego sensu i zależy jedynie od arbitralnej decyzji twórcy. Kształt wizualny staje się zatem na równi z semantyką tekstu orężem w prowokacji „wymierzonej smakowi publicznemu”. Widać to świetnie np. w utworze Sterna Pełnia księżyca 
nad morzem, w którym z rzadka pojawiają się jakieś przebłyski tradycyjnych znaczeń, całość oddziałuje zaś przede wszystkim swą stroną wizualną.

Ale typografia w „pierwszym polskim almanachu poezji futurystycznej” spełnia jeszcze jedną, być może najważniejszą, rolę. Otóż zarówno realizacje artystyczne, jak i manifest umieszczone zostały w publikacji pomiędzy dwoma "gga”. GGA pierwszym, tytułowym, inicjalnym, zapisanym przy użyciu „ciężkich” wersalików i „małym” gga, którym kończy się manifest prymitywistów:

gga. gga panowie wypadło na arenę świata, wywijając swoim podwójnym g, a krzyczy, a - to usta tego wspaniałego i ordynarnego bydlęcia, właściwie morda, pysk, albo ryj (Wat, Stern 2008: 9).

Można by więc powiedzieć, że wszystkie najbardziej rewolucyjne treści almanachu rozgrywają się pomiędzy GGA a gga. Aby zdeszyfrować „krzykliwe” wersaliki z okładki, czytelnik musi przeczytać całość, by na końcu znaczenie się odsłoniło. Zastosowana czcionka odgrywa tutaj niebagatelną rolę - po pierwsze, od razu niejako nakazuje poszukiwanie sensu zagadkowego tytułu, temu podporządkowując bieg lektury; po drugie, co istotniejsze, użyciem tak odmiennego liternictwa do zapisu tej samej sylaby zwraca uwagę na materialność słowa, co z kolei zgodne jest z postulatami manifestu prymitywistów:

SŁowA mają swoją wagę, dźwięk, barwę, swój rysunek. ZAJMUJĄ MIEJSCE W PRZESTRZENI. Są to decydujące wartości słowa. słowa najkrótsze (dźwięk) i słowa najdłuższe (książka). znaczenie słowa jest rzeczą podrzędną [...]. Główne wartości książki - to format i druk jej po nich dopiero - treść. Dlatego poeta winien być zrazem zecerem i introligatorem swej książki [...] (Wat, Stern 2008: 8).

Neofuturzy realizują więc w praktyce to, co postulują. Na dwa różne sposoby zapisane "gga” to metatekstowy zabieg mający na celu eksponowanie ikonicznego kształtu słowa, zrywający z przezroczystością wizualną zapisu, a w efekcie skłaniający, by widzieć pierwszy almanach futurystyczny jako wewnętrznie heterogeniczną całość ufundowaną na dynamicznym współwystępowaniu dwu mediów: językowego i obrazowego.

Inne jeszcze efekty przyniosła współpraca Wata z Henrykiem Berlewim. Jak pisze Jacek Ladorucki:

Ważnym twórcą w zakresie dizajnu wydawniczego międzywojennej Polski był Henryk Berlewi. Artysta zafascynowany również osobliwym 
pięknem i magią maszynowej automatyki, wprowadził do malarstwa i sztuki użytkowej technikę inspirowaną jej precyzją. Swoją koncepcję tworzenia nazwał „mechanofakturą”, a jej teorię opracował jeszcze w Berlinie, gdzie przebywał w latach 1922-1923 (Ladorucki 2018: 71)5.

Wraz z poetami Stanisławem Bruczem, Sternem i Watem Berlewi założył biuro ogłoszeń pod nazwą „Reklama-Mechano”. W związku z tą działalnością w 1924 roku opublikowana została szesnastostronicowa broszura Mechano-Faktura autorstwa Berlewiego ze wstępem Wata. Warto ten tekst przypomnieć, bo od momentu wydania nie był przedrukowywany:

Służąc apologii współczesności, wydawnictwo nasze dąży nade wszystko do oparcia nowej sztuki na trwałych podstawach, wolnych od anachronizmów, od dzisiejszej jałowej kazuistyki teoretycznej.

Dalecy od tych, których zadawalniają i podniecają do ekstazy pojęcia: natchnienie, twórczość, intuicja, talent itd., dalecy również od haseł tego rodzaju jak: śmierć sztuce, buddyzm europejski, rozpłynięcie się sztuki, rozpłynięcie się sztuki w industrii, które są, co najwyżej, radykalnym przeprowadzeniem anachronizmów minionego, pesymistycznego światopoglądu - pragniemy sprecyzować i udoskonalić środki sztuki, oprzeć ją na racjonalnym systemie metod, które opracowała i wypróbowała współczesność w innych dziedzinach, w dziedzinach industrii, wiedzy ścisłej, nauk ekonomicznych.

Praca niniejsza, rezultat długoletnich praktycznych i teoretycznych zabiegów jej autora, kładzie mocne fundamenty pod dyscyplinę plastyki współczesnej, pod ścisłą normatywną teorię sztuki (Wat 1924: 3-4).

Wstęp zapowiada, co po anarchizmie wystąpień neofuturów może dziwić, oparcie reguł tworzenia na zasadach racjonalnych ${ }^{6}$. Ale ten racjonalizm to, po pierwsze, sprzeciw wobec przebrzmiałych, anachronicznych wartości sztuki

5 Dalej czytamy: „Mechanofaktura nomen omen polegała na mechanicznym odtwarzaniu uporządkowanych, schematycznych form (linii prostych i form geometrycznych) za pomocą perforowanych szablonów. Kolorystyka ograniczała się do czerni i bieli, ożywionych niekiedy czerwienią. Koncepcja mechanofaktury pozwala uważać jej autora za prekursora późniejszego popartu i optycznego kinetyzmu” (Ladorucki 2018: 71).

6 Nota bene, warto zauważyć, że już w manifeście Gga pojawiło się hasło „zamiast ekstazy intelekt”. Graf pisze: „W moim przekonaniu futuryzm jest sztuką intelektualną” (Graf 2018: 10). 
minionej, dopiero po drugie, próba oparcia nowej teorii sztuki na wymiernym i logicznym wzorcu. Kilkunastostronicowy wykład Berlewiego doprecyzowuje, na czym owe racjonalne zasady mają polegać i jakim założeniom mają odpowiadać. Są to:

zerwanie ze wszelkim imitowaniem przedmiotów [...], autonomiczność form, dyscyplina, w najszerszym pojęciu tego słowa; jasność, pozwalająca każdemu orientować się w intencji artysty, schematyczność, geometryczność, precyzja, ułatwiające każdemu uporządkowanie wrażeń, otrzymanych przez dane dzieło - stara technika malarska nie odpowiada. Jeszcze bardziej bezsilną staje się owa rękodzielnicza technika, o ile chodzi o stworzenie nowego szematycznego systemu fakturowego. I w danym wypadku wyręczyć nas w stanie jest jedynie technika mechanistyczna wzorowana na technice industrialnej, niezależnej od kaprysów jednostki, opierającej się na ścisłej i dokładnej funkcji maszyny. Na zasadach więc wytwórczości oprzeć się powinno dzisiejsze malarstwo. dzisiejsza sztuka (Berlewi 1924: 14, por. Rudziński 1977: 205-217).

Praktyczną realizację tych postulatów przynosił prospekt reklamowy czekolady „Plutos” (Warszawa 1925):

Była to kilkunastostronicowa broszurka, o formacie $15 \times 15 \mathrm{~cm}$, drukowana na żółtym tle czerwoną i czarną farbą. Integralną część broszurki stanowił tekst Wata, wynoszący w specyficznym quasi-dadaistycznym języku opisywane czekoladki nad inne. Okładkę skomponowano z elementów typograficznych i literniczych, dzieląc płaszczyznę i horyzontalnie, i wertykalnie (Ladorucki 2018: 72).

Widać sposób, w jaki Berlewi wykorzystał elementy mechanofakturowe i konkretne rodzaje czcionek, by zaprojektować przestrzeń typograficzną.

Powyższe konstruktywistyczne projekty kształtowały się

pod wpływem Lissitzky’ego. Berlewi, według Piotra Rypsona, rozwinął w 1924 roku teorię sztukę „manufakturowej”, techniki mechanistycznej [wzorowanej - K.P.] na technice industrialnej, niezależnej od kaprysów jednostki, opierającej się na ścisłej i dokładnej funkcji maszyny, realizowanej w dziełach o zrytmizowanych układach form graficznych (Rypson 2017: 46). 
Zgodnie z tymi założeniami artysta wykorzystał elementy geometryczne: linie poziome, pionowe, łamane, równoległe, a także koło i kwadrat, wszystkim projektom nadając również formę kwadratu. W zakresie liternictwa posłużył się zarówno małymi, jak i wielkimi literami (z wyraźną przewagą wersalików), zastosował różne rodzaje podziału płaszczyzny, niektóre projekty oparł na układzie symetrycznym, który dynamizowaly zastosowane barwy (czerń i czerwień umieszczone na żółtym tle) oraz kierunki rozmieszczenia pisma. Dlatego té reklamowe prospekty czekolady „Plutos” przypominają grafiki, w których dominuje dynamiczny porządek występujących elementów oraz celowość zastoso-
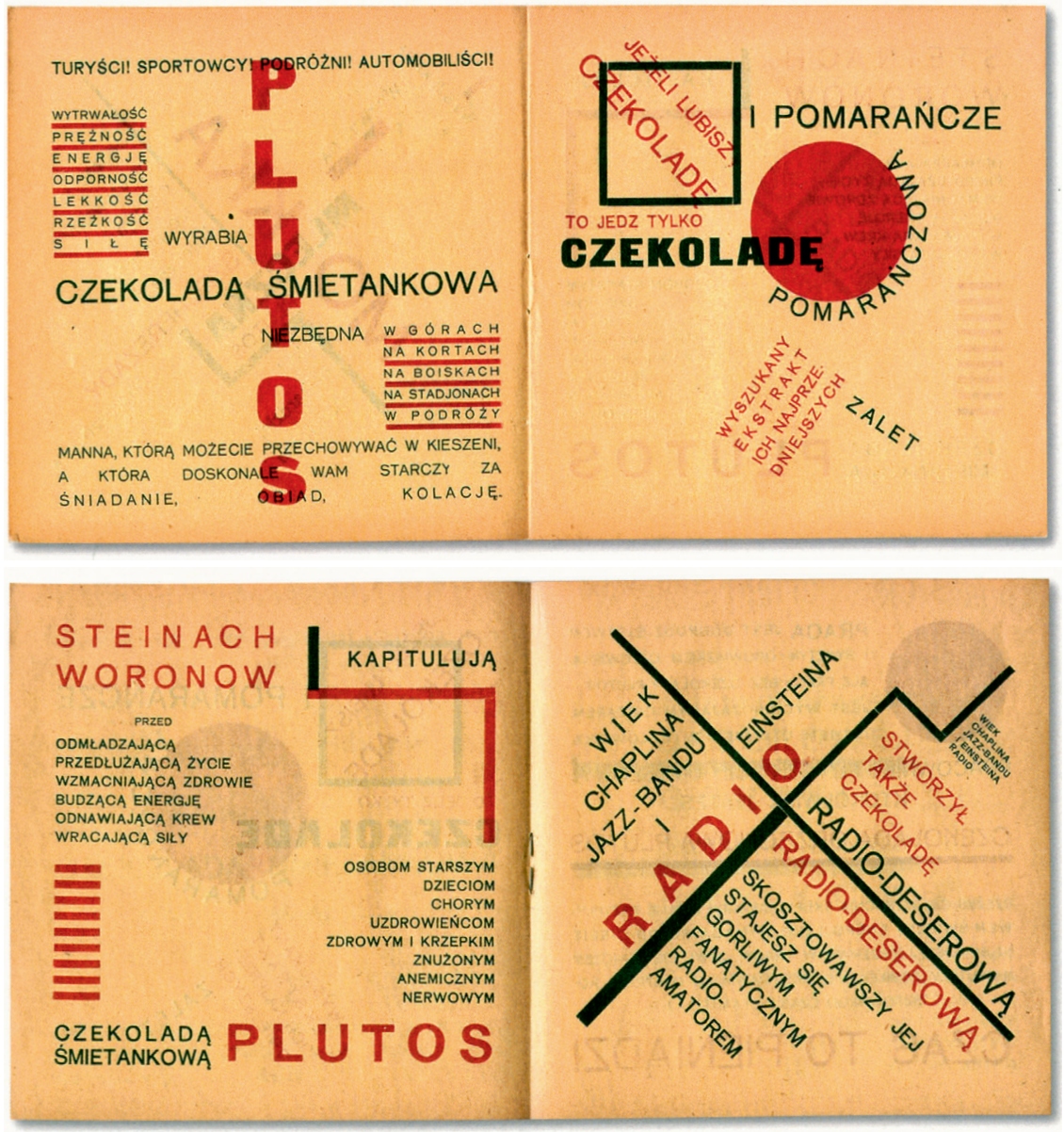

Ryc. 5. Projekty reklamowe czekolady Plutos 
wanych środków. Brak tutaj jakichkolwiek czysto dekoracyjnych komponentów czy detali, celem nadrzędnym jest bowiem przejrzystość i czytelność przekazu.

Jako autor tekstów Wat okazał się w dwudziestoleciu kreatywnym copywriterem, realizującym projekt reklamowy z dużą inwencją językową i poczuciem humoru. Warto kilka jego pomysłów przytoczyć in extenso:

Wyszukana i wykwintna mokka mleczna Plutos. Jedząc ją przeżywamy cudowne, nieopisane, bajeczne szecherezady smakoszostwa. Jest najbardziej egzotyczna.

Turyści! Sportowcy! Podróżni! Automobiliści! Wytrwałość, prężność, energię, odporność, lekkość, rześkość, siłę wyrabia czekolada śmietankowa „Plutos”, niezbędna w górach, na kortach, na boiskach, na stadionach, w podróży. Manna, którą możecie przechowywać w kieszeni, a która doskonale wam starczy za śniadanie, obiad, kolację.

Jeśli lubisz czekoladę i pomarańcze, to jedz tylko czekoladę pomarańczową - wyszukany ekstrakt ich najprzedniejszych zalet.

Steinach, Woronow kapitulują przed odmładzającą [czekoladą śmietankową „Plutos” - K.P.], przedłużającą życie, wzmacniającą zdrowie, budzącą energię, odnawiającą krew, wracającą siły osobom starszym, dzieciom, chorym, uzdrowieńcom, zdrowym i krzepkim, znużonym, anemicznym, nerwowym.

Wiek Chaplina, jazz-bandu i radio stworzył także czekoladę radio-deserową. Skosztowawszy jej, stajesz się gorliwym, fanatycznym radio-amatorem.

Podziwiając pochodzące sprzed niemal wieku zgrabne tekściki Wata, w których widać zamiłowanie do błazenady niegdysiejszego uczestnika skandalizujących, legendarnych wieczorów futurystycznych i w których dochodzi do głosu lingwistyczny zmysł autora namopaników, niepodobna nie zauważyć, że hasła reklamowe przekazane jedynie w kształcie językowym tracą siłę oddziaływania. Dopiero ich wersja graficzna nadaje słowom moc i dynamizm, ponieważ każe „czytać” tekst punktowo, nielinernie, „eksplozywnie”. Z kolei bez wymiaru językowego kolejne projekty w ogóle nie mogłyby zostać zrealizowane, ponieważ litera stanowi tu najmniejszy element konstrukcji. Jeśli nawet wyobrazić sobie, że poszczególne słowa zostają zastąpione innymi elementami (np. liniami różnej 
szerokości i koloru), to wówczas znika całkowicie wymiar semantyczny przekazu, a projekty stają się jedynie plastycznymi, geometryzującymi kompozycjami, w których brakuje głównej bohaterki reklamy, czekolady „Plutos”. Zatem czynnik wizualny i werbalny są tutaj równoprawne i nierozdzielne, współtworząc semantykę i wespół realizując finalny cel komunikatu. Prospekt reklamowy Berlewiego i Wata stanowi zatem intermedium w rozumieniu Dicka Higginsa, wedle którego, jak pisze Załuski, to:

realizacja łącząca w sobie cechy i elementy różnych sztuk, sytuująca się w obszarze pomiędzy już znanymi typami praktyk artystycznych. Tym, co liczy się przede wszystkim, jest fakt materialnego i pojęciowego stopienia się różnych środków wyrazu w jedną całość (Załuski 2010: 10).

Z taką właśnie syntezą mamy do czynienia w przypadku reklamy czekolady „Plutos”, nota bene produkowanej w dwudziestoleciu w fabryce czekolady na warszawskiej Ochocie. Co ciekawe, projekt ten nie został rozpowszechniony, zapewne okazał się na owe czasy zbyt śmiały i nowatorski, daleko wykraczając poza czysto komercyjne cele i doraźne potrzeby konsumenckie. Berlewiemu, „pionierowi awangardowej grafiki reklamowej w Polsce” (Rypson 2017: 46), i Watowi, eksperymentującemu w zawodzie copywritera awangardowemu poecie, nie udało się wprowadzić na rynek nowoczesnych pomysłów typograficznych. Projekt pozostał projektem, realizując udany mariaż rozwiązań plastycznych ze sztuką słowa.

Reasumując, w efekcie zwrotu obrazowego i podjęcia badań nad awangardowymi dokonaniami o charakterze wizualno-językowym w transmedialnej perspektywie wyraźnie widać, że wszystkie powyższe realizacje to media mieszane, łączące różne kody i adresowane do różnych praktyk percepcyjnych nakierowanych zarówno na aspekt ikoniczny, jak i na komunikat werbalny. We wszystkich dziełach wykorzystany został niezwykły układ drukarski, posługują się liternictwem różnego kroju, różnej wielkości i różnego koloru, nadto sytuując je na barwnym tle, przecinanym (w przypadku prospektu reklamowego) liniami wertykalnymi, horyzontalnymi, skośnymi oraz kołami i kwadratami, co w konsekwencji burzy spokojną linearność płaszczyzny przekazu, proponując w to miejsce ekspresywność i dynamikę, wymagające od odbiorcy większej kreatywności i innowacyjności w odczytywaniu znaczeń. Arsenał użytych środków w efekcie znacznie zwiększa siłę oddziaływania i tworzy przekaz celowy i funkcjonalny, adekwatny do semantyki. Zastosowana typografia nie jest jedynie wizualnym dodatkiem do treści komunikatu, lecz aktywnie go modyfikuje i współtworzy. 
Awangardowe eksperymenty typograficzne uświadamiają dziś, że wbrew wcześniejszym praktykom nastawionym na wyznaczanie autonomii poszczególnych sztuk, należy wyjść, jak postulował William J. Thomas Mitchell, poza porównywanie różnych dziedzin artystycznych. Według niego:

Problem obraz/tekst nie jest czymś, co zostaje skonstruowane „pomiędzy” sztukami, mediami lub różnymi formami reprezentacji, ale jest nieuniknionym problemem wewnątrz pojedynczych sztuk i mediów. Mówiąc w skrócie, wszystkie sztuki są „złożone” (z tekstu i obrazu), wszystkie media są splątanymi mediami, łączącymi różne kody, dyskursywne konwencje, kanały oraz sensoryczne i kognitywne środki komunikacji (cyt. za: Kałuża 2020: 46).

Działalność Wata, realizowana wespół ze Sternem i Berlewim, to jeszcze jeden aspekt jego młodzieńczych poszukiwań i eksperymentów, w mniejszym stopniu wykorzystujący potencjał znaczeniowy języka, w większym - złożony, wizualno-słowny charakter przekazu. Wat w rozmowie z Miłoszem powiedział, że chodziło mu wówczas o „gniecenie słowa”, „niszczenie słowa” (Wat 1998: 45) nie tylko w jego wymiarze akustycznym czy semantycznym, ale także, jak się okazuje, ikonicznym. Taki stosunek do języka jako materii, możliwość używania go niczym gliny sprawia, że elementy pierwotnie werbalne stają się formami wizualnymi. Usytuowanie młodzieńczych intermediów Wata w horyzoncie zwrotu pikturalnego pozwala odkryć i docenić „wyparty z kultury obrazowy sposób ustanawiania znaczenia/widzialności” (Kałuża 2020: 52) oraz uświadomić, że bez obrazu, swego materialnego, nieprzezroczystego nośnika, zapisane słowo nie istnieje.

\section{| Bibliografia}

Berlewi Henryk (1924), Mechano-faktura, Wyd. JAzz, Warszawa.

Graf Paweł (2018), Automobil w pędzie. Studia o futuryzmie i futurystach, Wydawnictwo Naukowe UAm, Poznań.

Jasieński Bruno (1978), Manifest w sprawie poezji futurystycznej, w: Antologia polskiego futuryzmu i Nowej Sztuki, wstęp i komentarz oprac. Zbigniew Jarosiński, wybór i przygotowanie tekstów Helena Zaworska, Ossolineum, Wrocław, s. 17-22. 
Jarosiński Zbigniew (1978), Wstęp, w: Antologia polskiego futuryzmu i Nowej Sztuki, wstęp i komentarz oprac. Zbigniew Jarosiński, wybór i przygotowanie tekstów Helena Zaworska, Ossolineum, Wrocław, s. III-CXXIII.

Kaczmarczyk Katarzyna (2017), O podstawowych założeniach narratologii transmedialnej i o jej miejscu wśród narratologii klasycznych i postklasycznych, w: Narratologia transmedialna. teorie, praktyki, wyzwania, red. naukowa Katarzyna Kaczmarczyk, Universitas, Kraków, s. 24-85.

Kałuża Anna (2020), Poezja i obraz, piśmienność i wizualność od 1989 roku, „Wielogłos", $\mathrm{nr} 1$ (43) s. 37-56.

Karpowicz Agnieszka (2010), Wizualność - pisemność. Wybrane funkcje pisma $w$ sztuce plastycznej Xx wieku, w: Antropologia pisma. Od teorii do praktyki, red. Philippe Artières, Paweł Rodak, Warszawa, s. 123-135.

Ladorucki Jacek (2018), Typografia to uderzenie, forma, ksztatt, konstrukcja. Szczuka, Strzemiński, Berlewi, Hiller, czyli polska awangarda artystyczna $w$ projektowaniu graficznym druków pierwszej połowy xx wieku w Polsce, „Annales Universitatis Paedagogicae Cracoviensis. Studia ad Bibliothecarum Scientiam Pertinentia", t. 16, s. 50-76.

Pietrych Krystyna (2017), Dadaistyczne z ducha poszukiwania młodego Wata, w: Impuls dadaistyczny w polskiej sztuce i literaturze dwudziestowiecznej, red. Paulina Kurc-Maj, Paweł Polit, Muzeum Sztuki w Łodzi, Łódź, s. $134-150$.

Rudziński Piotr (1977), Awangardowa twórczość Henryka Berlewiego, „Biuletyn Historii Sztuki”, nr 2, s. 205-219.

Rypson Piotr (2017), Nie gęsi. Polskie projektowanie graficzne 1919-1949, Karakter, Warszawa.

Śniecikowska Beata (2006), Słowo - obraz - dźwięk. Literatura i sztuki wizualne w koncepcjach polskiej awangardy 1918-1939, Universitas, Kraków.

Śniecikowska Beata (2019), TAK odnalezione! Pierwsze czytanie pierwszej ulotki polskich futurystów, „Teksty Drugie”, nr 3, s. 331-352.

Wat Aleksander (1998), Mój wiek. Pamiętnik mówiony, t. 1, rozmowy prowadził i przedmową opatrzył Czesław Miłosz, do druku przygotowała Lidia Ciołkoszowa, Czytelnik, Warszawa.

Wat Aleksander (2008), Wspomnienia o futuryzmie, w: tenże, Publicystyka, zebrał, oprac., przypisami i wstępem opatrzył Piotr Pietrych, Czytelnik, Warszawa, s. 134-155.

Wat Aleksander, Stern Anatol (2008), Prymitywiści do narodów świata i do polski, w: Wat Aleksander (2008), Publicystyka, zebr., oprac., przypisami i wstępem opatrzył Piotr Pietrych, Czytelnik, Warszawa, s. 7-13.

Załuski Tomasz (2010), Transmedialność? w: Sztuki w przestrzeni transmedialnej, red. Tomasz Załuski, AsP w Łodzi, Łódź, s. 9-18. 


\section{| Abstrakt \\ Krystyna Pietrych \\ Młodzieńcze intermedia Aleksandra Wata (Anatola Sterna i Henryka Berlewiego)}

Artykuł omawia trzy awangardowe dokonania Aleksandra Wata o charakterze wizualno-językowym, realizowane razem z Anatolem Sternem i Henrykiem Berlewim. Interpretacja w transmedialnej perspektywie ujawnia ich heterogeniczny charakter łączący różne kody - ikoniczny i werbalny. Rozpatrywane powyżej realizacje wykorzystują niezwykły układ drukarski, posługują się liternictwem różnego kroju, różnej wielkości i różnego koloru, zróżnicowaną grafią, co w konsekwencji burzy linearność płaszczyzny przekazu, proponując w to miejsce ekspresywność i dynamikę, wymagające od odbiorcy większej kreatywności i innowacyjności w odczytywaniu znaczeń. Zastosowana typografia nie jest w prezentowanych dziełach jedynie wizualnym dodatkiem do treści komunikatu, lecz aktywnie go modyfikuje i współtworzy.

Słowa kluczowe: awangarda; futuryzm; dadaizm; intermedialność; transmedialność

\section{| Abstract}

\section{Krystyna Pietrych}

\section{Youthful Intermedia of Aleksander Wat (Anatol Stern and Henryk Berlewi)}

The article discusses Aleksander Wat's three avant-garde achievements of a visual-linguistic nature, executed together with Anatol Stern and Henryk Berlewi. Interpretation in the transmedia perspective reveals their heterogeneous character, which combines various codes - iconic and verbal. The discussed works make use of an unusual printing layout, employ lettering of various typefaces and diversified graphics, which consequently disrupts the linearity of the plane of the message, offering in its place expressivity and dynamics, requiring from the recipient greater creativity and innovation in the reading of meanings. The typography used in the presented works is not merely a visual addition to the content of the message, but actively modifies and co-creates it.

Keywords: avant-garde; Futurism; Dadaism; intermediality; transmediality 


\section{| Nota o autorze}

Krystyna Pietrych - prof. uŁ, kierownik Zakładu Literatury i Tradycji Romantyzmu UŁ oraz Interdyscyplinarnego Centrum Badań Humanistycznych UŁ. Autorka monografii o poezji Aleksandra Wata (O „Wierszach śródziemnomorskich” Aleksandra Wata; Warszawa 1996) oraz edytorka jego pism (Dziennik bez samogłosek; Warszawa 2001). Następnie opublikowała „Co poezji po bólu?” Empatyczne przestrzenie (2009) oraz O czym (nie) mówią poeci? (2019). Główny obszar jej zainteresowań stanowi dwudziestowieczna poezja polska, pisała m.in. o wierszach Leśmiana, Tuwima, Baczyńskiego, Wata, Szymborskiej, Herberta, Białoszewskiego, Barańczaka, Iwaszkiewicza, Różewicza, Miłosza, Krynickiego, Sommera. Redaktor naczelna rocznika „Czytanie Literatury. Łódzkie Studia Literaturoznawcze”.

E-mail: pietrych@op.pl

ORCID: 0OOO-0001-9796-185X 